\title{
Historein
}

Vol $2(2000)$

Heterodoxies: Constructions of Identities and Otherness in Medieval and Early Modern Europe

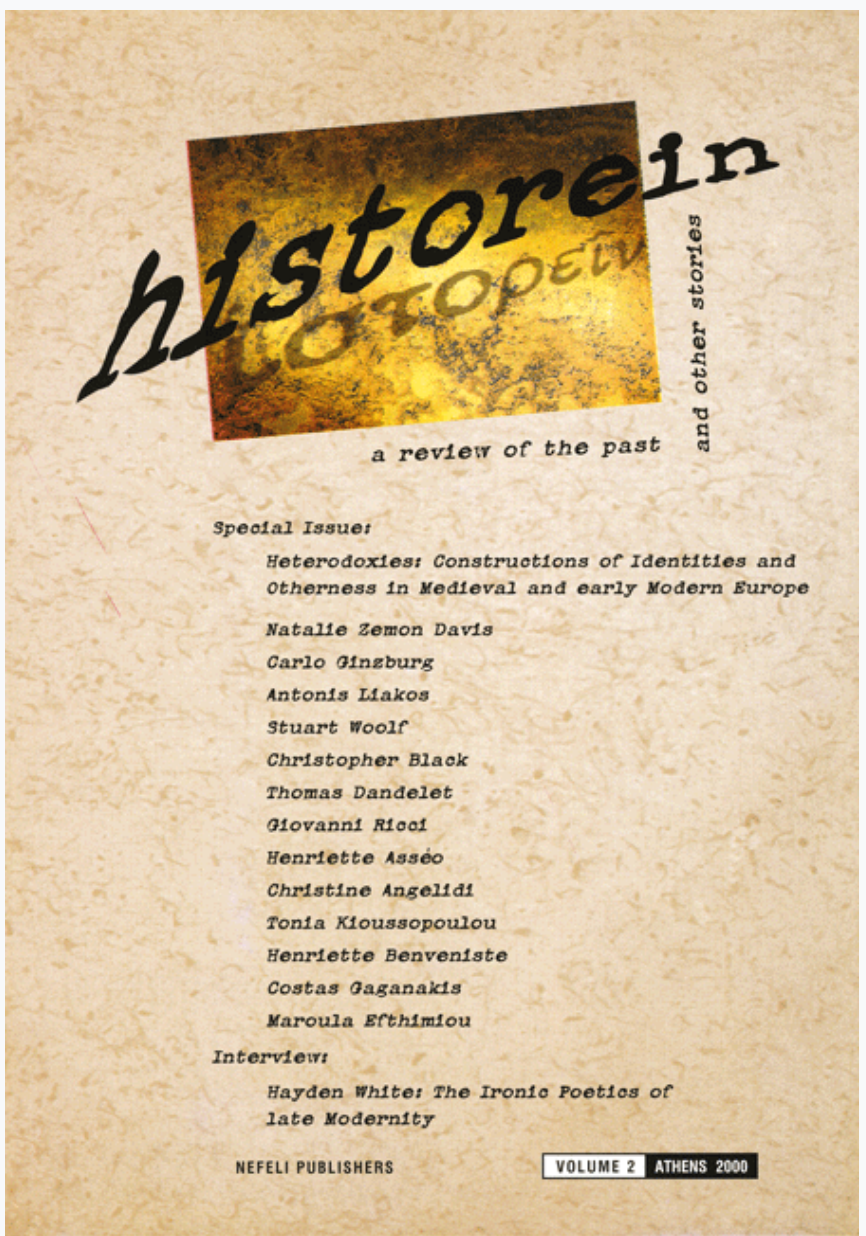

\section{Byzantine Heterodoxy and the Search for Identities: Some Thoughts on Byzantine Iconoclasm}

Christine Angelidi

doi: $\underline{10.12681 / \text { historein.117 }}$

\section{Copyright ( ) 2012, Christine Angelidi}

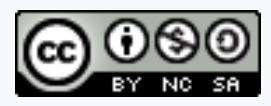

This work is licensed under a Creative Commons Attribution-NonCommercialShareAlike 4.0.

\section{To cite this article:}

Angelidi, C. (2001). Byzantine Heterodoxy and the Search for Identities: Some Thoughts on Byzantine Iconoclasm. Historein, 2, 123-134. https://doi.org/10.12681/historein.117 


\title{
Byzantine
}

\section{Heterodoxy}

\author{
and the
}

\section{Search for}

\section{Identities:}

\section{Some Thoughts}

on Byzantine

\section{Iconoclasm}

\section{Christine Angelidi}

The search for Byzantine identities by defining, first, 'otherness' as mirrored in texts and the visual arts, is a relatively new field of Byzantine studies. To reach this stage, two major issues had to be overcome: one, the scarcity of official or private documents that has prevented research from achieving large-scale results; two, the Byzantine 'imitation' of classical models, both literary and artistic, which obstructs our understanding of the available evidence. However, under the impulse of work carried out on Late Antique and Medieval history, recent research has shown a remarkable shift from traditional analysis to new scholarly techniques and disciplines. By using new methods of analysis, Byzantine research is broadening its scope and finds itself in a position to review a number of time-honoured certainties of the past.

To a certain degree, and in its strict sense, 'heterodoxy' is not a new subject for Byzantine studies. The christological disputes of the fourth and fifth centuries, Constantinopolitan attitudes towards the Church of Rome, the struggle against the Latin occupation of the Empire after 1204, and, of course, the fight against Islam, all form the traditional framework within which heterodoxy has been investigated. Further, heterodoxy in its broadest sense has been connected to the 'innere Geschichte' of the Byzantine Empire. A number of significant studies have clarified aspects of the structure and means of expression of specific groups, such as women, the old and the young, the sick and the insane, as well as of broader configurations, such as the family and forms of belief. Thus, it has been demonstrated that besides the need to reconsider traditional 
periodisation, identities and otherness cannot be clearly defined unless we depart from the formal discourse Byzantines themselves employed to describe whatever they considered collective or individual deviance from the perceived norm.

For the purpose of this paper I will consider heterodoxy as designating a partial or fragmentary discourse, which cannot properly be understood unless the features of the normative discourse from which it derives are defined. Further, I will argue that as far as Byzantine Iconoclasm is concerned, our search for identities can easily be obstructed by a series of fragmentary discourses that disclose only partial viewpoints. Finally, I intend to show that our evidence leads to 'fluid' rather than firmly established identities, and that any renewed attempt to reconstruct Byzantine identities during and after Iconoclasm has to posit a revised set of hypotheses.

The period of the Byzantine Dark Age, between the late Seventh and the mid-ninth century, would seem to offer the right field for testing our hypothesis on 'fluid' identities. Besides scarce literary and artistic evidence, a lack of manuscripts, and intense militarisation, this period is marked by the emergence of the Iconoclastic movement. The Iconoclast controversy and its ramifications for the whole of Byzantine society provide an important set of evidence that serves our purpose. Iconoclasm was a time of heterodoxy par excellence, and almost every aspect of social division or historical discontinuity it created has already been investigated. With this in mind, I shall reconsider the evidence concerning two topics on which so much has been written that any further investigation would seem pointless at first sight. However, my aim is to show that if we consider these specific topics from another viewpoint, we can draw interesting conclusions with regard to identity. My first example will focus on belief, while the second refers to an aspect of what is commonly understood as 'women's history'.

I shall not attempt to relate everything that happened in the Byzantine Empire between 726 and 843 (i.e. the beginning and official end of Byzantine Iconoclasm), nor shall I evaluate in detail the various interpretations of the Iconoclast controversy. Nevertheless, a brief historical account of the period may be useful. ${ }^{1}$

In the summer of 726 a tremendous submarine eruption occurred in the Aegean Sea, and was widely interpreted as a sign of divine displeasure towards the Christian Byzantine people. Previous signs were no less ominous. By the first decade of the eighth century, the Arab advance into Asia Minor regained momentum. In 716-717 the Arabs besieged Constantinople and ten years later, the enemy was inside the walls of Nicaea. During the siege something remarkable happened: while priests and pious citizens prayed for heavenly help, one of the defenders of the city, an officer of the Byzantine army, smashed the icon of the Virgin, which was suspended from the walls of the city, and soon after the Arab army withdrew. In late 726 (or perhaps some four years later), ${ }^{2}$ Leo III promulgated his famous edict by which icons of Christ and the saints were to be removed and denied veneration. ${ }^{3}$

Leo III himself was a man of uncertain identity. A native of Gemanikeia (Maraß), a town near the 
eastern frontier of the empire, Leo was bilingual, which means that he spoke Arabic or (more likely) a local Semitic dialect and Byzantine Greek. After spending his early youth in Byzantine Syria, Leo joined the army and served in Asia Minor and the Caucasus regions under Justinian II. By the time of his early career, he had changed his Christian name Conon to Leo, disavowed his Monophysite creed and embraced official Byzantine Orthodoxy. He then came to Constantinople and served for a time at court; soon, however, Anastasius II appointed him general (strategos) of the province (thema) of Anatolikon, and so he returned to Asia Minor to fulfil the duties of his office. In 716 Leo revolted against Theodosius III, the last in the dynastic line established by Heraclius a century earlier, and in March 717 he was proclaimed emperor.

In terms of his career Leo may be regarded as representing the views and interests of the Byzantine army in Asia Minor, whose effective military (and political) power was backed by landed property. It was also in Asia Minor that the old dispute over worship of icons had been revived by the local bishops some time before Leo's rise to the throne. ${ }^{4}$

Leo's policy against icons was supported, if not dictated, by bishops of Asia Minor. It may also have had some popular support among the inhabitants of Asia Minor. ${ }^{5}$ However, his first public move against icons - the alleged destruction of Christ's icon adorning the gate of the imperial palace at Constantinople - met the resistance of the Constantinopolitans. The veracity of this event, of which we are informed by much later sources, has recently been put in doubt. ${ }^{6}$

Iconoclastic policy reached its peak during the reign of Constantine V, son and successor of Leo III. In 754 Constantine convoked a Church council, by which he intended to provide Iconoclasm with a solid doctrinal basis. To prepare the discussion, research was undertaken in patristic literature and several corroborative passages were assembled. Little has survived of the minutes of the deliberations, but we possess several fragments of the doctrinal Definition in which the arguments against icons were summarised and anathemas pronounced. ${ }^{7}$ It was only after this council that Constantine undertook the persecution of icons and of their supporters, namely the monks. ${ }^{8}$

Allegedly, Constantine ordered the destruction of all iconic decoration in churches, the secularisation or destruction of Constantinopolitan monasteries, ${ }^{9}$ and even made the monks parade in the Hippodrome, each holding a woman by the hand. The persecution went as far as the external appearance of his subjects: himself beardless, he made shaving compulsory, thus creating a clearly visible distinction between his supporters and his opponents. ${ }^{10}$

In the long run the persecution proved ineffectual and served merely to harden the determination of the icon-worshippers. Ten years after Constantine's death the situation was sufficiently mature for a complete reversal. A Church council was, however, necessary in order to annul the Iconoclast positions within the Church and, by extension, the state. Thus, in 787 the empress Irene, supported by the monks, convoked the Council at Nicaea, ${ }^{11}$ which restored the worship of icons and strengthened the impact of the monasteries on the ecclesiastical and secular policy of the state.

However, the affair proved not to have been definitively closed. The disastrous military and 
economic policy of Irene and her successors, as well as the austere financial reforms introduced by Nicephorus I, resulted in general discontent among the Byzantines. By 814 Leo V decided to re-introduce Iconoclasm, a decision that was promptly followed by the death of the leader of the Bulgarian forces that were besieging the imperial city. The coincidence of these events taken as a sign from heaven, a special committee was again appointed to re-examine the scriptural and patristic basis of the Iconoclastic doctrine. In 815 , following the decisions of a new Church council, Iconoclasm was officially restored. ${ }^{12}$

Compared to the first Iconoclasm, the policy implemented by the emperors from 815 to 843 appears fairly mild. There is no mention of officially instigated destruction of icons, apart from the profanation of Christ's icon at the gate of the imperial palace, which had been allegedly restored by Irene some time after the Council of 787 . Persecutions were nominal: no massive deportation of monks, nor systematic destruction of monasteries is recorded. New argumentation was not advanced by the supporters of the rival factions in defence of their views, and there is little evidence of any real ideological fanaticism. The death of the last Iconoclastic emperor and the regency led by his widow, Theodora - surrounded by a constellation of courtiers - put the final seal on the Iconoclastic controversy. In 843, the 'Triumph of Orthodoxy' was celebrated in the church of St. Sophia and anathemas were pronounced against emperors and bishops who had supported the Iconoclastic 'heresy'. ${ }^{13}$ The restoration of icons forms just one aspect of the renewal of the Byzantine state. Another important aspect was the rise of a group of powerful military families. Their members had grown steadily more powerful during the reigns of Iconoclastic emperors, and by 843 they not only represented the aspirations of the army, but occupied important positions in the state apparatus.

Any study of Iconoclasm depends on evidence provided by texts construed according to the perspective of the Iconophiles, whose political and theological supremacy, between 787 and 815 and definitively after 843, placed Iconoclasts on the side of 'heterodoxy'. The evidence is, however, twofold, since it contains not only the propagation of the Iconophile viewpoint, but also refutations of Iconoclastic doctrine and, by necessity, explicit references to it. Twisted though it might be, this evidence has repeatedly been scrutinised; every theological, political, military and social aspect of the period has been commented on and interpreted. As Peter Brown put it, "the iconoclast controversy is in the grip of a crisis of over-explanation." ${ }^{14}$

Leo III's origins on the eastern frontier of Byzantium, his upbringing in a Semitic-speaking environment, his original Monophysite creed, and his familiarity with the Arabs have generally led students of the period to the conclusion that Byzantine Iconoclasm was closely related both to a heretical deviation from official Orthodoxy, as well as to an oriental non-iconic model, whether Islamic or Jewish. More recently, it has been argued that Iconoclasm was an exclusively internal affair of Byzantium. Moreover, it has been established that Iconoclasm constitutes only one aspect of the reaction against a critical co-occurrence of internal and external coercion. ${ }^{15}$ Additional evidence in favour of an Islamic or Jewish pattern overlying a deeply rooted Hellenistic 
and Roman tradition may be drawn from inose few works that did survive Leo's reign. On this issue Leo's legislative opus, the Ecloga, provides significant evidence. For the first time, the scriptural model of a religious state enters Byzantine legislation, until then purely secular. It is possible, therefore, to argue that Leo's 'Semitic' model included more than the issue of holy images. Stressing the Christian character of the Empire was quaking the Roman standards by which the Byzantines perceived their state. ${ }^{16}$

However, the religious aspect of the public domain was no novelty. One has to bear in mind that from the early seventh century onward, the Church and especially the monasteries promoted steadfastly and successfully the public side of belief and worship. Icons of Christ and the Virgin were used as apotropaic signs in the walls of the cities, and all icons were officially venerated." Seen within the context of Late Antique tradition, icons embodied the unity of specific social groups, and the multiplication of icons and of their forms of use during the seventh century has been interpreted accordingly. Thus, the division of the post-Justinian Byzantine Empire into smaller units, comprising a city and its region, may be viewed as somehow restoring a Late Antique model - but with a crucial difference. By the late-sixth century the local authorities, which symbolised the independence of the Hellenistic city, no longer existed. The disintegration of the network of Antique cities and the ruralisation of the Empire during the seventh century accelerated the crisis in social cohesion. The local saint ('holy man' in Peter Brown's terminology) appears then to function as the unifying element of the dispersed groups. Cults of local saints were promoted both by the Church and the monks. Effective during the saints' lifetime, the cults were perpetuated after their death by pilgrimages, gatherings in the monastery they had founded, and especially by the veneration of their icons. ${ }^{18}$

If by the reign of Leo III Iconoclasm was about reinforcing the centralised state against a centrifugal tendency (led in part by the local ecclesiastical authorities), i.e. if it was about controlling and dominating, then Constantine V's personal interest in doctrine and theology ${ }^{19}$ generated an additional factor in the controversy. Few Iconoclastic writings have survived the purge carried out by Iconophiles after 843 , but we possess a number of the so-called 'Inquiries' of Constantine, which were refuted in detail by the Iconophile Patriarch Nicephorus. ${ }^{20}$ In their surviving form, the Inquiries present no sustained argumentation; and this was most probably their original form as well - a kind of working paper to be submitted to the fathers of the Iconoclastic Council. Taken as a whole the Inquiries consider only two things as holy: the Eucharist given to mankind by God himself together with the ecclesiastical space consecrated by bishops ${ }^{21}$ and the cross, the sign of the true faith presented by God to the first Christian emperor, Constantine the Great. With regard to icons, the Iconoclastic discourse is categorical: no icon can claim holy status, because no icon has been sanctified by the blessing of a priest. ${ }^{22}$ It is according to this exegetic framework that icons were to be deprived of their authority and replaced by the cross. ${ }^{23}$

The Inquiries and the Definition adopted by the Iconoclastic Council set in motion a highly sophisticated discourse of refutation, especially concerning the theology of the icon ${ }^{24}$ Old 
reasoning was revived and systematic investigation of ancient texts (both biblical and patristic) - a method already used by the Iconoclasts - provided Iconophiles with stronger counterarguments. Byzantine authors and modern research have used the icon issue as the most reliable indicator for distinguishing Iconoclastic from Iconophile texts. However, the debate on the worship of icons should normally have been just one among many other criteria of the theological and ecclesiastical order dividing Byzantines into Iconoclasts and Iconophiles. But if we examine sources of the eighth and ninth century that do not deal with icons and try to apprehend their orientation we are confronted with important difficulties.

Take the example of a curious text, the Ecclesiastical History and Mystical Contemplation, which besides primary liturgical material, contains elements of a theory of symbolic interpretation. Any evaluation of this treatise within the Iconoclastic or Iconophile framework comes up against problems of dating, authorship, and content. The oldest manuscript tradition ascribes the text to Basil of Caesarea, and considers the History as an appendix to Basil's liturgy. ${ }^{25}$ However, the Basilean tradition seems to date only to the tenth century, whereas our text had already been translated in Latin during the 870 s by Anastasius the Librarian. ${ }^{26}$ Anastasius himself attributes the History, though with some reluctance, to Germanos, ${ }^{27}$ the patriarch of Constantinople, deposed in 730 because he refused to embrace the Iconoclastic policy of Leo the III. Moreover, the liturgical basis of the History reveals an intermediary stage between early liturgy and its codified form from the tenth century onwards. The attribution to Germanos is, thus, generally admitted as the most plausible.

In spite of its title, the Ecclesiastical History is not a history of the Church as an institution. Germanos' purpose is to explain the liturgy, which he considers as the continuation of the divine history as taught in the Bible; the message of the salvation disclosed by the sacrifice of the Word, as performed during Eucharist, marks the fulfillment of divine historical time.

In developing his ideas Germanos proceeds according to a well defined scheme, which combines the detailed account of the ecclesiastical space, the officiants, and the gestures performed both by the clergy and the assembly during the prayer with their 'hidden', symbolic meaning. Thus, in a kind of preamble he explains the areas of the Church which are linked to the holy office, then he moves on to an enumeration of the garments of the clergy and of the sacred objects. The explanation/interpretation of the liturgy forms the core of the treatise, first with the liturgy of the Catechumens, then the liturgy proper: the Great Entrance, the conveyance of the holy objects to the altar, the sacrament and holy communion. ${ }^{28}$ Throughout the text, Germanos insists on two issues: the fusion of the Old with the New Testament, and the cosmological symbolism of the cross. Icons are not mentioned in the text; their absence may be attributed to the structure of the text, a commentary on the liturgy, in which icons played no part. It is nevertheless noteworthy that one of the most important texts on Byzantine liturgy, in particular a text authored by a patriarch, praised for his adherence to icon worship, focuses on the scriptural model of history, the cross, and the Eucharist, ${ }^{29}$ three topics that form the core of Iconoclastic theology. 
Let's now return to the Christ-on-the-palace-gate episode, related by strongly Iconophile sources. ${ }^{30}$ The story runs roughly as follows: in 726 or in 730 , Leo III ordered the destruction of Christ's icon, an act that provoked a riot among the citizens of Constantinople. The rioters pulled down the ladder from which an emperor's agent was standing as he was destroying the icon. As a result, they were put to death. Their intact bodies were found in 869 , were venerated as relics of martyrs, and the account of their martyrdom was included in the Acta Sanctorum and the official Synaxarium of the Great Church of Constantinople. Now, the episode is related by several sources, which differ in important details. I will focus only on one of them, namely the composition of the crowd of martyrs.

The earlier version of the gate-martyrdom is included in the Vita Stephani junioris, a martyr of the first Iconoclasm, and records the involvement of certain 'pious women', which in the contemporary historiography are substituted by a group of citizens of outstanding nobility and culture. The women appear also in another text, the forged letter of Pope Gregory II to Leo III, fabricated around the year 800. Women are definitively recorded in all texts dating from the tenth century on. What can we deduce from these accounts? How is the role of women to be interpreted?

The importance of women as champions of icons has often been underlined. ${ }^{31}$ The key role of the empresses Irene and Theodora in the restoration of the cult of icons has been viewed accordingly as reflecting a collective female attitude: in the words of a leading Byzantinist, "during iconoclasm feminine weakness turned out to be more steadfast than masculine strength." ${ }^{32} \mathrm{~A}$ closer investigation of our evidence allows us, however, to question this axiomatic formulation.

All accounts of the Christ-on-the-gate incident are structured on the basis of contrasting pairs: high-ranking officials versus soldiers of humble origin, educated people versus people with no education. Considered in this perspective, the female element stands as the first component of a third pair: weak women versus strong men. This binary opposite structure reminds one of the narrative strategies used in hagiography, a literary genre extensively exploited by the supporters of icon worship to propagate the martyr-like deeds of Iconophiles. ${ }^{33}$ Traditionally, women belong to the outcast groups, which allegedly gave their lives for the cause of the true faith - already in the early period of Christianity - and they stand in a privileged position in early hagiography. Women reappear in the hagiography of the ninth and tenth century, but this time they serve different purposes and are invested with different features: they are the mothers and the faithful wives, who chose to dedicate their lives to God after the death of their personal torturers, their rude and ruthless husbands. ${ }^{34}$ Their sainthood was discreet, exercised behind closed doors - no social convention was ever broken. The portraits of the empresses Irene and Theodora as depicted in historical writings and saints' lives follow this family-oriented pattern: they were pious and achieved sainthood by suffering patiently their husbands' deviations from the true faith. They had at last their fifteen minutes of saintly fame, when, widowed, they worked on the restoration of icons.

To what extent does this family pattern conform to the women-at-the-gate episode? The story is 
known only from Iconophile sources and family values are generally held to have been propounded by Iconophile milieus. However, the family and temperate women were praised as well in Iconoclastic legislation and Iconoclastic hagiography. ${ }^{35}$ We may, then, deduce that positive perception of the female element is not a secure indicator for attributing texts to either of the groups in conflict.

Moreover, both Iconophile and Iconoclastic documents record instances of women seen under a negative light. For example, several edifying texts considered to date in their actual form to the ninth or tenth century, but which probably have their origins in eighth-century Iconophile milieus, describe women destroying icons - women of socially improper demeanour, women sexually provoking holy men and monks. ${ }^{36}$ The woman-witch haunts the Iconophile imaginary. Removed from the icon-veneration context, the rioting women may easily be identified with such a group of undesirable outcasts made to be scapegoats. Following the conclusions of a recent study, we may consider our story as reflecting an Iconoclastic discourse, that denounces the 'enemy' (the monks?) by diminishing his supporters, women. This tale was subsequently taken up by the Iconophiles. It was embellished with the addition of well-born women, adjusted to the needs of the hagiographic narrative and included in saints' lives, alleged Letters of Popes, entries in the Synaxaries, and so on. ${ }^{37}$

Heterodoxy is self-evident as far as Iconoclasm is concerned. Learned research has shown the mechanisms by which Byzantium became by the ninth century a medieval state. The struggle for power led by the representatives of the army against the remnants of the late Roman aristocracy has been thoroughly analysed. The changes in landed property and in the status of the peasantry have been studied with reference to the downfall of the Antique network of independent cities, and the phenomenon of estates granted to the soldiers. Important work has been done on the family, and on women and their key-role with regard to the restructuring of the Byzantine society. The means of expression, in particular the historiography and the correspondence of the time, have been the subject of several research projects. We know much about the forms of belief, their antecedents and their transformation into an institutional Byzantine Orthodoxy by the second half of the ninth century. In a word, we are now well informed about a series of fragmentary discourses or, to put it better, of the mechanisms by which identities and conscious or unconscious otherness were constructed. What we lack, however, are the threads that might have functioned as cohesive links between the different groups. I think, therefore, that for the time being Byzantine research has learned enough about heterodoxy as a criterion for otherness. In one way or another some aspects of the Byzantine reality will always remain obscure, and it is doubtful whether new material will change this situation. Nevertheless, a fresh look at our available evidence may lead to more fluent formulations about identities, particularly since 'fluid' identities were neither typical of, nor unique to, the Dark Age of Byzantine Iconoclasm. 
${ }^{1}$ For a more detailed survey see C. Mango, "Historical Introduction", in A. Bryer \& J. Herrin (eds), Iconoclasm. Birmingham 1977, pp. 1-6; cf. J. F. Haldon, Byzantium in the Seventh Century. Cambridge 1990, pp. 84-91 (for the period 717-741).

${ }^{2}$ This chronological discrepancy depends on the interpretation of the available sources. For a discussion of the evidence, see S. Gero, Byzantine Iconoclasm during the Reign of Leo III. Louvain, 1973, pp. 94-98; cf. also J. Herrin, The Formation of Christendom. London, 1987, p. 334ff.

${ }^{3}$ On the implications of Leo's iconoclastic policy soon after 726, see D. Stein, Der Beginn des byzantinischen Bilderstreites und seine Entwicklung bis in die 40er Jahre des 8. Jahrhunderts. Munich 1980, pp. 138-193.

${ }^{4}$ Opposition to the cult of icons dates from the 4th century; for a survey see E. Kitzinger, "The Cult of Images in the Age before Iconoclasm", Dumbarton Oaks Papers, 8 (1954), pp. 129-134.

${ }^{5}$ See, for instance, the letters Germanos, Patriarch of Constantinople, addressed to bishops of Asia Minor, and dated around 730: Stein, Der Beginn des byzantinisches Bilderstreites, pp. 4-88, especially pp. 82-87.

${ }^{6}$ See the detailed analysis of the sources by M.-F. Auzépy, "La destruction de l'icône du Christ de la Chalcé par Léon III: Propagande ou réalité", Byzantion, 60 (1990), pp. 445-492. The author concludes that the icon has never been destroyed for the simple reason that it has not existed before 787 .

${ }^{7}$ Shorter or lengthier fragments of the Definition are quoted in the minutes of the Council of 787 , where they served as corroborative material of the iconoclastic 'heresy'. The fragments are conveniently published by H. Hennephof, Textus Byzantinos ad Iconomachiam pertinentes. Leiden, 1969, nos. 200-264 (with bibliography p. 61).

${ }^{8}$ M.-F. Auzépy, "La place des moines à Nicée II (787)", Byzantion, 58 (1988), pp. 5-21, especially p. 7, questions the assertion of the Iconophile sources, composed after 787 , which represent monks as forming a solid anti-Iconoclastic tagma. The 'resistence' of the monks would date only after 765 , when Constantine $\checkmark$ attempted to compel them to embrace his policy under oath.

${ }^{9}$ In fact, evidence shows that only a few Constantinopolitan monasteries suffered by Constantine's policy.

${ }^{10}$ However, the formalised, bearded imperial portrait continued to be engraved on the monetary issues of Constantine $\mathrm{V}$, the main 'innovation' introduced by the 720 s being the exclusion of Christ's representation on the coins. For the evolution of the numismatic evidence under the Isaurians, see, Ph. Grierson, Catalogue of the Byzantine Coins in the Dumbarton Oaks Collection and in the Whittemore Collection, III. Leo III to Nicephorus III (717-1081), Part I. Leo III to Michael III (717-867). Dumbarton Oaks, 1973, pp. 110 and 146. The shaving of beards may be seen as the reaction against the monks' long beards, thus as the external feature of the struggle against monasticism; it constitutes also a lesser element of the revival of the Roman imperial tradition, on which the political theory of the Iconoclastic emperors relied.

${ }^{11}$ The Constantinopolitan army, however, tried to dissolve the Synod by invading the Church of St Sophia. In a remarkable show of force Irene overcame the difficulty by ordering the transfer of the rebel armies from Constantinople to Asia Minor. On the monks during the Council, see Auzépy, La place des moines.

${ }^{12}$ On the Council and its deliberations, see P. J. Alexander, "The Iconoclastic Council of St. Sophia (815) 
Byzantine Heterodoxy and the Search for ldentities

and its Definition (Horos)", Dumbarton Oaks Papers, 7 (1953), 35-66. On the appointed Committee see P. J. Alexander, The Patriarch Necephorus of Constainople. Oxford, 1958, pp. 126-7.

${ }^{13}$ J. Gouillard, "Le Synodikon de l'Orthodoxie. Édition et commentaire", Travaux et Mémoires, 2 (1967), pp. $1-316$

${ }^{14}$ P. Brown, "A Dark Age Crisis: Aspects of the Iconoclastic Controversy", The English Historical Review, 88 (1973), repr. in his Society and the Holy in Late Antiquity. New York, 1982, p. 254; cf. P. Schreiner, "Der byzantinische Bilderstreit: Kritische Analyse der zeitgenössischen Meinungen und das Urteil der Nachwelt bis heute", in Bisanzio, Roma e Italia nell' alto medioevo. Spoleto, 1988, pp. 319-427.

${ }^{15}$ On the Islamic element in Byzantine Iconoclam see Gero, Byzantine Iconoclasm during the Reign of Leo III. pp. 59-93; cf. 0. Grabar, "Islam and Iconoclasm", Iconoclasm (op. cit., n. 1), pp. 45-52. The Jewish background has been discussed by L. Barnard, The Graeco-Roman and Oriental Background of the Iconoclastic Controversy. Leiden, 1974, pp. 34-50; cf. P. Speck, Ich bin's nicht, Kaiser Konstantin ist es gewesen. Bonn, 1990, passim. On the Monophysite element see, S. Brock, "Iconoclasm and the Monophysites", Iconoclasm (op. cit., n. 1), pp. 53-57; see also P. Crone, "Islam, Judeo-Christianity and Byzantine Iconoclasm", Jerusalem Studies in Arabic and Islam, 2 (1980), pp. 59-95. For a general discussion see J. F. Haldon, "Some Remarks on the Background to the Iconoclast Controversy", Byzantinoslavica, 38 (1977), pp. 161-184.

${ }^{16}$ On the particular forms of Byzantine 'caesaropapism' under the Iconoclastic emperors, see G. Dagron, Empereur et prêtre. Paris, 1996, pp. 169-250. The 'theological' character of the Isaurian perception of royalty is set forth in the Preamble of the text, promulgated in 741 and primarily dealing with civil law: see, Gero, Byzantine Iconoclasm during th reign of Leo III, pp. 48-58 (with an Engl. trans. of the Preamble), and L. Burgmann (ed.), Ecloga. Das Gesetzbuch Leons III. und Konstantinos' V. Frankfurt, 1983.

${ }^{17}$ Kitzinger, "The Cult of Images", passim. On icons used as palladia, ibid., pp. 109-112. On the development of the icon worship during the sixth and the early seventh century, see A. Cameron, "Images of Authority: Elites and Icons in Late Sixth-Century Byzantium", Past and Present 84 (1979), pp. 3-35 (especially 18-35), repr. in her Continuity and Change in Sixth-Century Byzantium. London, 1981, pt. XVIII.

${ }^{18}$ P. Brown, Society and the Holy in Late Antiquity, pp. 103-165 and his, "A Dark Age Crisis", op. cit., pp. 265-270 (but see also the criticism of Barnard, The Greaco-Roman Background, pp. 144-145); Kitzinger, “The Cult of Images", pp. 95-115; Herrin, The Formation of Christendom (op. cit., n. 3), p. 307ff.; J. F. Haldon, Byzantium in the Seventh Century. Cambridge, 1990, pp. 405-424.

${ }^{19}$ Gero, Byzantine Iconoclasm during the Reign of Constantine V, pp. 143-151.

${ }^{20}$ In the First and the Second Antirrhetici of Nicephoros, written some time after 818: Hennephof, Textus Byzantinos, nos. 141-187; cf. G. 0strogorsky, Studien zur Geschichte des byzantinischen Bilderstreites. Breslau, 1929, pp. 7-45, and the analysis of Gero, Byzantine Iconoclasm during the Reign of Constantine V, pp. 37-52.

\footnotetext{
${ }^{21}$ Hennephof, Textus Byzantinos, nos. 226 and 184.

${ }^{22}$ Brown, "A Dark Age Crisis", 258 n. 30.
} 
${ }^{23}$ A. Grabar, L'iconoclasme byzantin. Dossier archéologique. Paris, 1984 (2nd ed.), p. 174ff.

${ }^{24}$ Especially the three speeches of John of Damascus 'against those who calumniate the icons'; ed. B. Kotter, Die Schriften des Johannes von Damascus, vol. III. Berlin - New York, 1975; cf. the survey of the Iconophile and Iconoclastic discussion over icons by L. Barnard, "The theology of Images", Iconoclasm (op. cit. n. 1), pp. 7-13. On the philosophical aspect of iconophile literature, see M.-J. Mondzain-Baudiner, "La relation iconique à Byzantce au IXe siècle d'après Nicéphore le Patriarche: un destin de l'aristotelisme", Études Philosophiques, 1 (1978), pp. 85-106.

${ }^{25}$ Basil of Caesarea appears in the lammata of 36 manuscripts dating from the tenth to the eighteenth century: R. Bornert, Les commentaires byzantins de la divine liturgie du VIle au XVe siècle. Paris, 1966, pp. 142-144.

${ }^{26}$ An expert on the diplomatic relations between Rome and Constantinople, Anastasius traveled to Constantinople in 869 to negotiate a projected marriage alliance between Byzantium and the Roman Empire. As Louis II's envoy he patricipated also in the Constantinopolitan council of 869-870. His translation has been published by S. Petrides, "Traités liturgiques de saint Maxime et de saint Germain traduits par Anastase le Bibliothécaire”, Revue de l'Orient Chrétien, 10 (1905), pp. 289-313, 350-363 and A. Rocchi, "Expositionis liturgicae de sacris graece obeuntis textus sincerus sancti Patris nostri Germani patriarchae Constantinopoleos", in A. MAI \& J. Cozza-Luzzi, Patrum nova bibliotheca, 10 (1905), II/a, pp. 3-28.

${ }^{27}$ ut graeci ferunt or ut fertur are the exressions of Anastasius. The manuscript tradition ascribing the History to Germanos comprises only seven manuscripts of the 13th to the 18th century: Bornert Les commentaires byzantins, pp. 144-145.

${ }^{28}$ On the importance of the text for the history of the liturgy and the transformations of the ecclesiastical space, see Th.F.Mathews, The Early Churches of Constantinople. Architecture and Liturgy. Pennsylvania: State University Press, 1971, p. 115.

${ }^{29}$ Cf. S. Gero, "The Eucharistic Doctrine of the Byzantine Iconoclasts and its Sources", Byzantinische Zeitschrift, 68 (1975), pp. 4-22.

${ }^{30}$ A thorough analysis of the sources can be found in Auzépy, "La destruction de l'icône du Christ de la Chalcé par Léon III" (op. cit., n. 6).

${ }^{31} \mathrm{~J}$. Herrin, "Women and the faith in icons in Early Christianity", in R. Samuel \& G. Stedman-Jones (eds), Culture, Ideology and Politics in Early Christianity. London, 1982, pp. 56-83; cf. her, "In Search of Byzantine Women: Three Avenues of approach", in A. Cameron \& A. Kuhrt (eds.), Images of Women in Antiquity. London, 1993, pp. 167-183, and The Formation of Christendom, p. 307ff., pp. 331-332.

${ }^{32}$ A. P. Kazhdan, "Byzantine Hagiography and Sex in the Fifth to the Twelfth Centuries", Dumbarton Oaks Papers, 44 (1990), p. 132.

${ }^{33}$ On historical narratives of the ninth century construed according hagiographical patterns, see Auzépy, "La destruction de Christ de la Chalcé par Léon III", pp. 59-460.

${ }^{34}$ E. Patlagean, “L'histoire de la femme déguisée en moine et l'évolution de la sainteté féminine à Byzance", Studi Medievali 3rd ser., 17 (1976), pp. 597-623 (repr. in her Structure sociale, famille, chrétienté à 


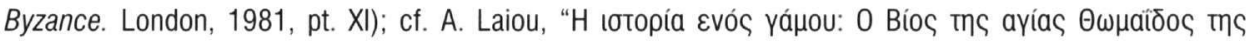

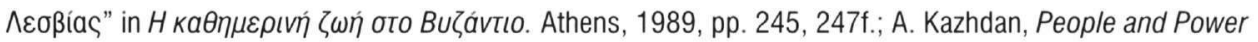
in Byzantium. Dumbarton Oaks, 1982, pp. 73, 112.

${ }^{35}$ Cf. A. P. Kazhdan \& A.-M. Talbot, "Women and Iconoclasm", Byzantinische Zeitschrift, 84/85 (1991/1992), p. 403f.; M.-F. Auzépy, "De Philarète, sa famille, et de certains monastères de Constantinople", in Les saints et leurs sanctuaires à Byzance. Paris, 1993, pp. 117-135, passim.

${ }^{36}$ E. Von Dobschütz, Christusbilder. Leipzig, 1899, p. 221**-223**; M.-F. Rouan (Auzépy), "Une lecture 'iconoclaste' de la Vie d'Étienne le Jeune”, Travaux et Mémoires, 8 (1981), p. 430.

${ }^{37}$ R. Cormack, "Women and Icons, and Women in Icons", in L. James (ed.), Women, Men and Eunuchs. Gender in Byzantium. London-New York, 1997, pp. 41-43. 